\title{
Impact of Perceived Desirability, Perceived Feasibility and Performance Expectancy on Use of IT Innovation: Technology Adoption Decisions and Use Behaviour
}

\author{
S. Moghavvemi \\ University of Malaya, Malaysia \\ S.W. Phoong \\ University of Malaya, Malaysia \\ S.T. Lee \\ University of Malaya, Malaysia
}

\begin{abstract}
Theoretical perspectives from the field of entrepreneurship can be used to examine entrepreneurs' intention to use IT innovations. This study collected 412 completed survey responses from entrepreneurs and used structural equation modelling to test the proposed technology acceptance decision model. The results showed the significant effect of perceived desirability, perceived feasibility and performance expectancy as the salient antecedents of intention to adopt and use IT innovation. This study examined the effect of external factors which prevent or facilitate the adoption and use of new technology. The moderating effect of the propensity to act is examined and the results indicated that when the individual propensity to act is high, taking action becomes more desirable and feasible. This study revealed that, in the current IS environment, individuals adopt and use a new system due to the attractiveness of the system and perceived feasibility, which are derived from intrinsic interest and affective beliefs.
\end{abstract}

Corresponding Author:

Dr. S. Moghavvemi is a Senior Lecturer at the Department of Operation and Management Information System, University of Malaya, Kuala Lumpur, Malaysia. E-mail: sedigheh@um.edu.my 


\section{Keywords}

Entrepreneurial Potential Model, IT Innovation, Precipitating Events, Technology Adoption Decision

\section{Introduction}

A large and growing body of research has investigated IT adoption and use behaviour by developing several models to explain the user acceptance of IT innovation (e.g., Straub, 2009; Koivumaki \& Kesti, 2008; Venkatesh, Morris, Davis \& Davis, 2003; Moghavvemi et al., 2016). Researchers used technology acceptance model (TAM), unified theory of acceptance and use of technology (UTAUT), and technology adoption decision and use (TADU) to investigate the determinants of individuals' intention to adopt and use new technology. However, Venkatesh, Davis and Morris (2007) claimed that many prior studies on technology acceptance were replications with no substantive theoretical advancements and with only minor tweaks and/or extensions. Venkatesh, Thong and Xu (2012) developed UTAUT2 to address the issue of replications in IT adoption research. They added hedonic motivation, price value, and habit to the UTAUT model and introduced UTAUT2 to understand consumers' IT adoption behaviours. The results of their research and many other studies in technology acceptance reveal that performance expectancy is the main and most significant factor that affects individuals' intentions to use new technology, while there are mixed results on the effect of other factors such as ease of use, subjective norms, and facilitating conditions in different studies. Considering these results (particularly regarding the ease of use factor), technology developers have attempted - to a certain extent - to design a technology that is easy to use and useful for the users. Consequently, to assist ease of use, most new technologies include appropriate instructions and manuals. As such, difficulty of use is not a major issue for users of any new technology. In addition, many facilities (e.g., video provided through social media such as YouTube) are made available to guide users on any technology and support systems are created to teach new users to easily use the new technology.

However, experience and observation show that many technologies have been introduced to the market that are easy to use and useful, but nevertheless fail to successfully capture or enter the market. It seems that individuals' intentions to adopt and use technology are affected by other 
factors apart from ease of use and usefulness which the previous literature and empirical studies have identified as the critical and salient factors. The question remains: what are the factors affecting individuals' acceptance or rejection of new technology which researchers in technology acceptance may have ignored and/or overlooked?

A review of the literature on individual intentional behaviour showed that researchers in entrepreneurship highlighted the effect of perceived desirability and perceived feasibility on individuals' intentions to take action. They argued that individuals will take action if the new task or action is attractive for them and if they feel personally capable of performing the task or action, regardless of whether the task is difficult or easy (Krueger \& Brazeal, 1994; Krueger, Hansen, Michl, \& Welsh, 2011). As long as the individual finds the new task to be attractive and they are capable of handling it, they would perform the intended behaviour. Perceived desirability and perceived feasibility are the two factors in the entrepreneurial potential model (EPM) which measure entrepreneurs' perceptions when starting a new venture or performing intentional behaviour (Krueger \& Brazeal, 1994; Krueger, Hansen, Michl, \& Welsh, 2011).

By applying entrepreneurship research in the technology acceptance context, we can argue that the attractiveness of using new technology and individual feasibility are two factors which affect individuals' adoption and use of new technology. We can argue that, at the beginning, an individual will consider the attractiveness of the new technology and their desirability to use it. If it is unattractive, and they lack the desire to use it, they will most probably ignore the new technology. The lack of attractiveness and desire to use may be the reasons why many new useful technologies introduced in the market have failed and could not command the attention of consumers. Therefore, the key factors when introducing technologies are the desirability and attractiveness of the technology to the target audiences. If desirability and attractiveness are satisfied, an individual may adopt and use the new technology if they also perceive the technologies to be feasible for them, regardless of how user-friendly a technology might turn out to be. As such, in this study we propose a technology adoption decision model that focuses on the factors of perceived desirability and perceived feasibility. Due to the 
role of performance expectancy as a significant determinant of individuals' intentions to use technology, the model proposed in this study includes performance expectancy and provides a combination of three factors that affect individuals' adoption and use of new technology. We assume that individuals will use the new technology if the new technology is attractive to them (perceived desirability), helps them improve their performance (performance expectancy), and they feel capable of using it (perceived feasibility). In addition, this study examined the prominent role of precipitating events and propensity to act and investigates how these factors contribute to improving the ability of perceived desirability and perceived feasibility to predict the intention to use technology. Applying this model in the technology acceptance context may identify the other factors which affect individuals' intentions to adopt and use IT innovation apart from ease of use and usefulness.

\section{Theoretical Background}

\section{Entrepreneurial Intention Behaviour}

Shapero (1982) developed the entrepreneurial event model as the first comprehensive intentionality model in the context of entrepreneurship. The entrepreneurial event model posits that the decision to perform an entrepreneurial activity requires a pre-existing attitude toward the activity as desirable and feasible, as well as a propensity to act on opportunity (Krueger, 2000; Mhango, Marcketti \& Niehm, 2005). Desirability and perceived self-efficacy thus form a foundation for entrepreneurial intention behaviour.

Krueger and Brazeal (1994) developed and theorized the EPM which emphasizes the constructs of perceived desirability and perceived feasibility by integrating the conceptualization of these constructs from both the entrepreneurial event model and the theory of planned behaviour (TPB) (Coduras, Urbano, Rojas \& Martinez, 2008; Veciana, Aponte \& Urbano, 2005). As shown in Figure 1, EPM theorizes that an entrepreneurial event requires the potential to start a business, which in turn depends on the relative credibility of alternative behaviours, plus some propensity to act, without which significant action may not be taken (Krueger \& Brazeal, 1994). 
Figure 1: Entrepreneurial Potential Model

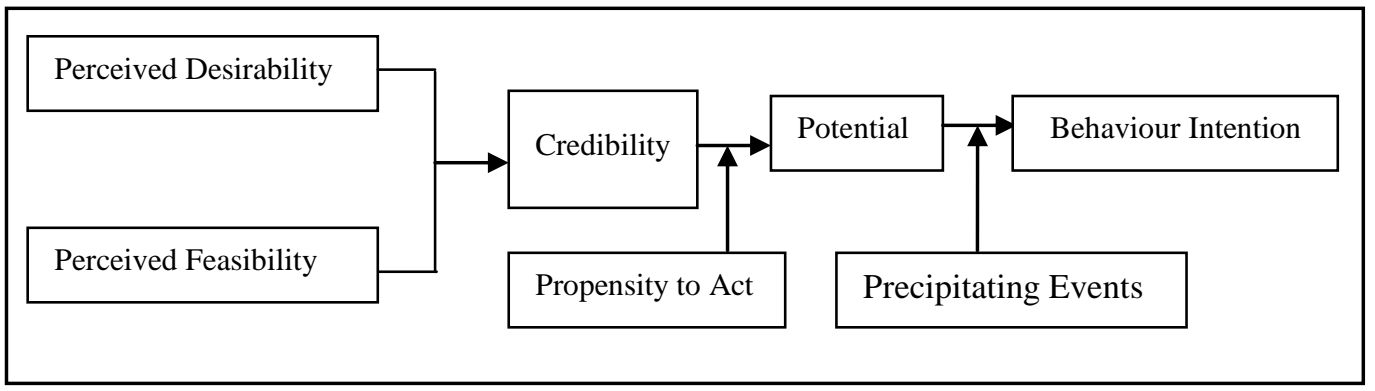

Source: Adapted from Krueger \& Brazeal, 1994, p. 95.

The EPM defines credibility based on two critical constructs, namely, desirability and feasibility (Guerrero et al., 2008; Krueger et al., 2000). Perceived desirability is the degree to which individuals find the prospect of starting a business to be attractive (Krueger, 1993). Perceived feasibility refers to the extent to which the individual feels personally capable of starting a business or performing the task. Krueger (1993) defines perceived feasibility as the entrepreneur's perception of their ability to carry out a specific behaviour. Although similar to the concept of self-efficacy in IS research, the concept of perceived feasibility in the EPM is not only concerned with the skills possessed by the individual, but also with the individual's judgment of what they can do with whatever skills they possess (Cheung et al., 2002).

The EPM defines the propensity to act as the personal disposition to act on one's decisions. Krueger (1993) posits that without significant propensity to act, it is hard to imagine well-formed intention. Propensity to act shows a volitional aspect of individual intention. Moreover, the EPM postulates that there are other factors such as significant life events (job loss, migration) which can also cause sizable increases in individual activity and change individual perception of new circumstances, signified by precipitating events (Krueger \& Schulte, 2008).

The literature on entrepreneurial intention defines intention as an individual's willingness to pursue a given behaviour. It is argued in the literature that intention is the best predictor of any planned behaviour 
(Stopford \& Baden-Fuller, 1994). It represents individual commitment to the target behaviour (Krueger, 2000). The EPM assumes that inertia guides human behaviour until something interrupts or displaces that inertia. These displacements (precipitating events) accelerate a change in an individual's behaviour (Krueger \& Brazeal, 1994). These precipitating events are certain exogenous variables that facilitate or precipitate the realization of intention into behaviour; for example, change in a work situation, change in environmental conditions, technological change, or change in an entrepreneur's career (Katz, 1992).

Researchers in entrepreneurship have used the EPM to understand entrepreneurs' intentional behaviours. For example, Dissanayake (2014) used EPM to examine entrepreneurial intention among the students in Sri Lanka. In a similar study Simanjuntak et al. (2016) examined the influence of formal education and self-concept on entrepreneurial potential among the students in Indonesia. Curral at al. (2013) conducted study among entrepreneurs and highlighted four main dimensions of entrepreneurial potential including entrepreneurial motivations, social competencies, psychological competencies, and management competencies. Segal et al. (2005) used the EPM to understand the motivation to become an entrepreneur among undergraduate business students. Similarly, Linan and Santos (2007) applied and revised the EPM to examine cognitive factors among undergraduate students. Nasurdin et al. (2009) validated the entrepreneurial intention among working adults, students and unemployed people by investigating the relationship between role models, social norms and entrepreneurial intentions and found that perceived desirability mediates between role models and social norms on entrepreneurial intention. Shook and Bratianu (2008) examined Romanian students' entrepreneurial intention and found that self-efficacy and desirability were positively related to entrepreneurial intention when creating a venture. Veciana et al. (2005) used university students to study potential entrepreneurs and demonstrated that these students had favorable perceptions of desirability but their perceptions of feasibility were not very positive regarding the new venture creations. Guerrero et al. (2008) found that the students' perceptions of feasibility were negative when creating a new firm, but they did consider it to be desirable. Oruoch (2006) and Zampetakis (2008) used college students and budding entrepreneurs to investigate the effect of perceived desirability and 
feasibility on the intention to create a venture and entrepreneurial experience.

Most of these studies focused on examining the determinants that influence individuals to become an entrepreneur, rather than on entrepreneurs' intentions to adopt IT innovation. In addition, prior studies on IT adoption have focused on the intention to use IT innovation among consumers, employees and individuals for their task-related purposes, rather than the perspective of entrepreneurs' behaviours related to technology adoption and usage.

\section{Research in Technology Acceptance}

Prior research in technology acceptance has focused on understanding the IS adoption behaviour by individuals and organizations. As a consequence, several IS adoption models have been developed and proposed to explain users' acceptance and use of IS (e.g., Davis, 1989; Tornatzky \& Fleischer, 1990; Venkatesh \& Zhang, 2010). IS researchers have proposed a variety of determinants that may influence IS adoption behaviour. For example, Tornatzky and Fleischer (1990) point out that the factors that affect IS adoption can be categorised into three main factors: (1) organizational, (2) technological, and (3) environmental. Kimberly and Evanisko (1981) suggest that organizational leaders' characteristics, organizational characteristics, and environmental characteristics are the determinants of IS innovation adoption. Other researchers argued that adoption behaviour is influenced by attributes of the innovation, characteristics of individuals, and environmental factors (Damanpour \& Schneider, 2006; Roger, 1995; Tornatzky \& Fleischer, 1990; Cheng, 2015; Sam \& Chatwin, 2015). Ajzen and Fishbein (1985) posit in their theory of reasoned action that individuals would use an information system if they could predict a positive outcome related to using the system. Davis et al. (1989) developed the TAM which is the first model specifically developed for IS adoption research to explain the determinants of IS acceptance by individuals. The TAM posits that a user's intention to use is determined by two constructs that act as the foundation for the TAM, namely, perceived usefulness and perceived ease of use. Davis et al. (1989) considers both perceived usefulness and perceived ease of use as the determinants of attitude and intention to use. 
Taylor and Todd (1995a) added perceived ease of use and perceived usefulness to the TPB to create a new model to predict inexperienced users' behaviours in the face of new technology compared to experienced users. They referred to the model as augmented TAM or combined TAM and TPB.This combined TAM and TPB (C-TAM-TPB) has the capacity to predict IS usage behaviour for individuals who have never used an information system before, as well as individuals who have used IS (e.g., Moore \& Benbasat, 1991; Taylor \& Todd, 1995a; Thompson et al., 1991). Davis (1992) employed the motivation theory to investigate the role of intrinsic and extrinsic motivations in explaining how individuals respond to IS adoption in healthcare. Intrinsic motivation refers to the perceived enjoyment of using technology and is the degree of pleasure experienced by individuals when using the computer. Igbaria, Parasuraman and Baroudi (1996) applied the motivation theory by conceptualising motivations into three main factors, namely, perceived usefulness, perceived playfulness, and social pressures, to investigate individual use of microcomputers.

Venkatesh (1999) adopted motivation theory to compare training methods and included a component with the aim of enhancing intrinsic motivation with traditional methods. Venkatesh (1999) found that users in game-based training interventions who had a more enjoyable experience during training were more likely to perceive the system to be easier to use, which led to increased behavioural intention. Thompson et al. (1991) proposed a model of personal computer utilization to predict individual acceptance and use behaviours. This theory was based on the Triandis (1977) theory of human behaviour.

Roger (1995) developed the innovation diffusion theory which posits that there are five general attributes of innovation that can persuade individuals to adopt an innovation, namely, relative advantage, complexity, trialability, observability, and compatibility. Karahanna, Straub and Chervany (1999) combined these aspects of innovation diffusion theory with the theory of reasoned action to investigate potential adopters and users of the Windows application. They found that there were significant differences among pre-adoption and post-adoption antecedents of behavioural intention. Another essential theory that IS researchers have extensively used to examine IS adoption behaviour is social cognitive 
theory. Compeau and Higgins (1995) extended social cognitive theory to include the concept of computer self-efficacy, and applied it to investigate the role of people's beliefs about their skill to competently use computers.

Venkatesh et al. (2003) compared and reviewed the eight most prominent IS adoption models adopted and adapted by IS researchers to predict IS adoption behaviour. Venkatesh et al. (2003) merged all eight models according to the core constructs, beliefs, and moderators and developed the UTAUT. Venkatesh and Zhang (2010) conducted research to extend the understanding of cultural differences as a boundary condition in IS adoption based on UTAUT via a longitudinal study of employees in a single organization that operated in China and the United States. Their findings indicated the importance of social influence among all the employees in China without possibilities related to age, voluntariness, and gender, which differed from their conclusions regarding the US sample. Park et al. (2007) employed the UTAUT to investigate mobile communication technology and argued that performance expectancy was more significant in shaping Chinese users' attitudes followed by effort expectancy. Wang et al. (2010) examined the acceptance of mobile learning by adding the two new constructs of perceived self-management of learning and perceived playfulness to the UTAUT. They reported that all the core determinants were significant in the intention to use mobile learning, with performance expectancy as the strongest determinant of behavioural intention. Evidently, all these studies reveal the significance of performance expectancy as the most crucial determinant of behavioural intention. However, mixed results have been reported for other core constructs such as effort expectancy and social influences. Some studies revealed the significance of these constructs as determinants of behavioural intention, while the majority of studies found no significant roles for effort expectancy and social influence in behavioural intention. Venkatesh et al. (2012) added the three constructs of hedonic motivation, price value, and habit to the UTAUT and developed UTAUT2 to tailor the model to understanding the IS adoption behaviours of consumers. Their study found that UTAUT2 explained 74 per cent of the variance in behavioural intention and use of IT by consumers. A review of the literature on technology acceptance revealed that few studies consider the attractiveness of the technology and individual feasibility to adopt and use the new technology, while studies in other 
contexts such as entreprenurship have shown that perceived desirability and perceived feasiblity are significant factors which affect an individual's intention to take action (Krueger \& Brazeal, 1994; Krueger et al., 2000). Applying these factors in the technology acceptance context will improve our understanding of individual behaviours related to technology adoption and use.

\section{Research Model and Hypotheses}

This study extends and validates the EPM in the context of technology acceptance in order to examine entrepreneurs' intention to adopt and use IT innovation. Applying and conceptualizing the EPM in the context of IT acceptance brings a new perspective to the IS adoption research area. The proposed technology adoption decision model uses two independent variables, namely, perceived desirability and perceived feasibility, and two moderating variables, namely, propensity to act and precipitating events, from the EPM. The items are conceptualized in the technology acceptance context (see Appendix 1) to measure the entrepreneurs' perceived desirability, perceived feasibility and propensity to use IT innovation. Performance expectancy is adapted from the UTAUT (Venkatesh et al., 2003).

The technology adoption decision model is employed to test entrepreneurs' intentions to adopt and use IT innovation in their business. This research defines IT innovation as any kind of IT that is new or has not been used by the entrepreneur even though the IT may be commonly used by others (e.g., mobile commerce, online banking service, mobile banking). As shown in Figure 2, the integrative model considers performance expectancy, perceived desirability, and perceived feasibility as the determinants of the behavioural intention to use IT innovation. 
Figure 2: Technology Adoption Decision Model

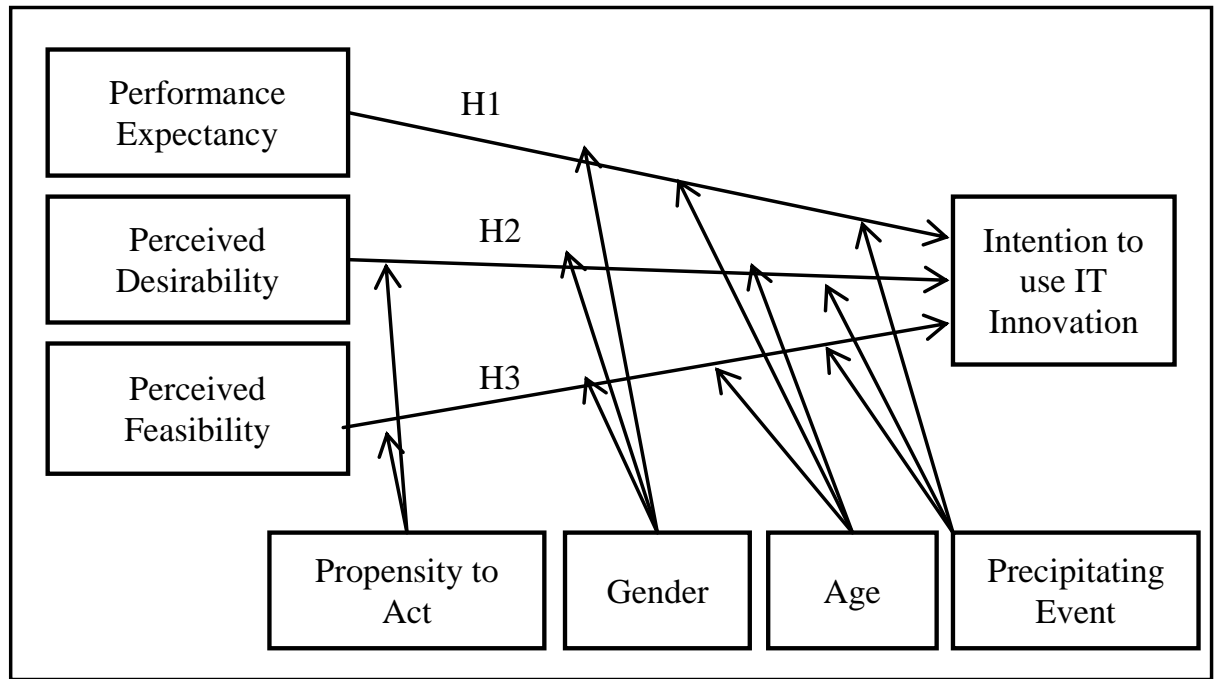

Source: Authors

The UTAUT suggests that performance expectancy is the strongest predictor of intention, which is significant at all points of measurement in both mandatory and voluntary settings (Venkatesh et al., 2003). Performance expectancy is important to individuals as individuals are more likely to adopt and use IT innovation if they can gain benefit and improve performance (Venkatesh \& Zhang, 2010). Typically, entrepreneurs are more concerned about the benefits they can gain from new opportunities that enhance enterprise performance (Tsai, 2009). Therefore, this study expects that entrepreneurs would consider using an IT innovation if it is useful and can enhance their enterprise's performance. Based on previous research in technology acceptance, this study defines performance expectancy as the degree to which entrepreneurs believe that using the innovation will help them attain gains in their enterprise's performance. Therefore, entrepreneurs will use an IT innovation based on their expectations of the outcome. If they expect that using the IT innovation will give them new opportunities and enhance their business situation and revenue, they will use it.

Morris and Venkatesh (2000) found that the effect of age and gender on performance expectancy was stronger for males and younger people. It is argued that the effect of performance expectancy is stronger for these groups as they are task-oriented, and extrinsic rewards are more important 
to them (Venkatesh et al., 2003). Therefore, it is expected that age and gender moderate the relationship between performance expectancy and intention to use IT innovation among entrepreneurs, as expressed in the following hypotheses:

H1: Performance expectancy has a positive effect on entrepreneurs' intention to use IT innovation.

H1a: The relationship between performance expectancy and entrepreneurs' intention to use IT is moderated by gender and age.

Shapero et al. (1982) defined perceived desirability as the degree of attraction an individual perceives towards a specific behaviour in the context of entrepreneurship. Prior studies demonstrate that higher levels of perceived desirability will lead to higher levels of behavioural intention to take action (e.g., Fitzsimmons \& Douglas, 2011). Perceived desirability is shaped through family, peers, culture, colleagues and mentors (Shapero et al., 1982). Conceptualizing the results of entrepreneurial research in the context of technology acceptance, perceived desirability measures the attractiveness of the technology to an individual and their favorable attitude toward adopting and using the IT innovation. This study conceptualizes perceived desirability as the degree of attraction an entrepreneur perceives towards using IT innovation that leads them to use the new technology in their company (Krueger et al., 2000).Therefore, this study postulates that perceived desirability has a significant influence on entrepreneurs' intention to use IT innovation and that the effect of perceived desirability on intention will be different among entrepreneurs based on age and gender. These points are expressed in the following hypotheses:

H2: Perceived desirability has a positive effect on entrepreneurs' intention to use IT innovation.

H2a: The relationship between perceived desirability and entrepreneurs' intention is moderated by gender and age.

Perceived feasibility is derived from Bandura (1986; 1995) who argues that taking action requires consideration of not just perceived desirability but also perceived feasibility. Perceived feasibility reflects the perception of 
a personal capability (individual capability) to do a particular job or set of tasks (Bandura, 1995). It is about an individual's ability and their judgment of their capability to use innovation (Straub et al., 2009). This study defines perceived feasibility as the entrepreneur's perception of their skills, knowledge and ability to use an IT innovation in their business (Souitaris et al., 2007). A higher level of perceived feasibility will lead to higher intention to use IT innovation. If entrepreneurs perceive they have enough skills and ability to use new technology in their work, they would be more interested to use it. Thus, a high level of perceived feasibility will increase the level of the entrepreneur's intention to use IT innovations. We assume that the effect will be different among male and female entrepreneurs. These points are expressed in the following hypotheses:

H3:Perceived feasibility has a positive effect on entrepreneurs' intention to use IT innovation.

H3a:The relationship between perceived feasibility and entrepreneurs' intention is moderated by gender and age.

Krueger and Brazeal (1994) explained that, although entrepreneurs perceive the new venture creation as desirable and feasible, these perceptions may not lead to the realization of the intended behaviour if the precipitating events (e.g., environmental events, technical change, government policy, and new markets) are lacking.Shapero et al. (1982) and Krueger et al. (2000) defined precipitating events as certain exogenous variables that facilitate or precipitate the realization of intention into behaviour. Precipitating events come in different guises and are different in the eyes of the beholder (Guerrero et al., 2008). Shapero (1982) and Krueger et al. (2008) demonstrated how significant life events can cause a sizable increase in entrepreneurial activity and change an individual's perceptions due to new circumstances. Tangible barriers and the subtleness of cognitive barriers can be obstacles that prevent an intention from coming to fruition (Shapero, 1982). Shapero (1982) posited that some sort of precipitating event is the leading cause of perceived personal opportunity. Triggering events create sudden changes in a person's life and work conditions by changing the individual's needs. The reaction to displacement is related to the perception of the influence of that event (Shook \& Bratianu, 2008; Tsai, 2009). Therefore, this study considers precipitating events as a moderating 
variable that captures the role of external factors in the technology adoption decision model, as expresed in the following hypotheses:

H4a:The relationship between the level of performance expectancy and entrepreneurs' intention is moderated by precipitating events.

H4b:The relationship between the level of perceived desirability and entrepreneurs' intention is moderated by precipitating events.

H4c:The relationship between the level of perceived feasibility and entrepreneurs' intention is moderated by precipitating events.

Shapero (1982) defined the propensity to act as the individual's disposition to act on their decisions (stable personal characteristics) which reflected the volitional aspects of intentions ("I will do it"). Propensity to act is a stable personality trait and closely related to the locus of control (Krueger et al., 2000). Krueger (2000) argued that without significant propensity to act, it is hard to imagine well-formed intentions. Individuals may have great potential to take action without corresponding intentions and the appropriate attitude may not be enough. Krueger and Brazeal (1994) examined the role of propensity to act and its ability to predict entrepreneurial intention and found a significant and positive relationship between them. Krueger and Brazeal (1994) found that, in conditions where the propensity to act is high, taking action becomes more desirable and feasible. Thus, this study postulates that intention to use IT innovation will be high and positive if the entrepreneurs' propensity to act is high:

H5a:The relationship between the level of performance expectancy and entrepreneurs' intention is moderated by the propensity to act.

H5b:The relationship between the level of perceived desirability and entrepreneurs' intention is moderated by the propensity to act.

H5c:The relationship between the level of perceived feasibility and entrepreneurs' intention is moderated by the propensity to act. 


\section{Data Analysis}

This study conducted a questionnaire survey to test the technology adoption decision model. The population was actual entrepreneurs who were involved in various industries. Based on McDaniel's (2000) definition, not all managers or owners of businesses are entrepreneurs because an individual can run a business without trying new ways of doing business. Thus, an entrepreneur is someone who does new things or does things that are already done in an innovative way (Schumpeter, 1936). Therefore, the target population of this study was entrepreneurs who brought ideas, new practices (products, services or methods of production), or innovation to their business, started a new business, or marketed new innovation. In total, 1,000 questionnaires were distributed through convenience random sampling during workshops and seminars organized for entrepreneurs by government agencies and private agencies in Kuala Lumpur, Malaysia. To ensure the respondents were entrepreneurs (i.e., entrepreneurs who brought ideas, new practices or innovation to their business, started a new business, or marketed a new innovation), the questionnaire specifically asked respondents to state whether they considered themselves as entrepreneurs. In addition, two filter questions were added which separated entrepreneurs from non-entrepreneurs at the beginning of the questionnaire. Of the 420 returned questionnaires, eight questionnaires were completed by nonentrepreneurs. The final number of usable questionnaires for analysis was 412, which was a response rate of 41.2 per cent consisting of 74 per cent male and 26 per cent female respondents, of whom 40 per cent were 31 to 39 years old, and more than 30 per cent were in the service industry.

It was concluded that non-response bias was not an issue in this study as there were no substantial differences in the makeup of the actual survey entrepreneurs and the sampled respondents (Armstrong \& Overton, 1977). This study used constructs that were adapted and pre-validated (see Appendix 1) in prior studies with 7-point Likert scale items, ranging from 1 'strongly agree' to 7 'strongly disagree'. Harman's single factor test (Podsakoff et al., 2003) confirmed that the data was free of common method variance. Confirmatory factor analysis (CFA) in structural equation modelling (SEM) suggested there was no problem regarding the common method variance. 
This study used SEM to test the hypotheses, with AMOS as the main statistical analysis tool. SEM is a multivariate technique that combines aspects of multiple regression, and is able to estimate a series of interrelated dependent relationships simultaneously (Hair et al., 2006). The hypothesized moderation model is tested in the core model based on two group models (Hair et al., 2006).

\section{Assessment of Measurement Model}

The primary approaches for measurement item purification include multiple iterations with the maximum likelihood estimation method that iteratively improves parameter estimates to minimize a specified fit function, and ensuring that stable maximum likelihood estimation solutions are as small as 100 to 150 of the sample size (Hair et al., 2006). Based on this purification test, some items for the constructs were deleted from the model to improve the model fit indices. The result for the final fit for the model in the calibration sample was excellent, with chi-square $=550.08$, GFI=0.90, $\mathrm{TLI}=0.95, \mathrm{CFI}=0.96$, RMSEA=0.06, and $\mathrm{CMIN} / \mathrm{DF}=2.32$. Next, CFA was used to assess the unidimensionality, reliability convergent validity, and discriminant validity to ensure that the set of measured items actually reflect the theoretical latent constructs (Hair et al., 2006). Table 1 presents the results on the composite reliability, average variance extracted (AVE) and correlation.

Table 1: Composite Reliability, Average Variance Extracted, Correlation

\begin{tabular}{|l|c|c|c|c|c|c|c|c|}
\hline Construct & $\mathbf{C R}$ & $\mathbf{A V E}$ & $\mathbf{1}$ & $\mathbf{2}$ & $\mathbf{3}$ & $\mathbf{4}$ & $\mathbf{5}$ & $\mathbf{6}$ \\
\hline $\begin{array}{l}\text { Performance } \\
\text { expectancy }\end{array}$ & 0.923 & .864 & $\mathbf{. 9 2 9}$ & & & & & \\
\hline $\begin{array}{l}\text { Perceived } \\
\text { desirability }\end{array}$ & .932 & .832 & $.710^{* *}$ & $\mathbf{. 9 1 2}$ & & & & \\
\hline $\begin{array}{l}\text { Perceived } \\
\text { feasibility }\end{array}$ & .936 & .886 & $.760^{* *}$ & $.732^{* *}$ & $\mathbf{. 9 4 1}$ & & & \\
\hline Propensity to use & .874 & .794 & $.667^{* *}$ & $.699^{* *}$ & $.619^{* *}$ & $\mathbf{. 8 9 1}$ & & \\
\hline $\begin{array}{l}\text { Precipitating } \\
\text { events }\end{array}$ & .886 & .811 & $.343^{* *}$ & $.381^{* *}$ & $.363^{* *}$ & $.319^{* *}$ & $\mathbf{. 9 0 0}$ & \\
\hline Intention to use & .893 & .858 & $.721^{* *}$ & $.710^{* *}$ & $.716^{* *}$ & $.695^{* *}$ & $.368^{* *}$ & $\mathbf{. 9 2 6}$ \\
\hline
\end{tabular}

Note: Values on the diagonal are the square root of the AVE; CR=Composite reliability; * $\mathrm{p}<0.05 ; * * \mathrm{p}<0.01$ 
The CFA indicated that the standardized parameter estimates of the model were higher than 0.70 , and the signs of parameter estimation were all in the same direction to measure specific latent variables. The overall model fit indices were in excellent positions and the standardized regression weights were all higher than 0.50 , thus confirming that the constructs were unidimensional. The composite reliability on all constructs was greater than 0.70 (from 0.85 to 0.89 ) and the AVE values were higher than 0.50 , thus supporting the reliability of all constructs (see Table 1). Meanwhile, the magnitudes of the standardized parameter estimations were higher than 0.50 , and the directions to measure specific latent variables were all the same with all estimated parameters statistically significant between the latent and measured variables, suggesting convergent validity was achieved. The chi-square difference test indicated that the models were statistically significant, with all $\chi^{2}$ differences significant at $p<0.01$ level. The fit indexes for the unconstrained models were all better than the constrained models, indicating strong support for the discriminant validity criterion.

\section{Testing the Hypotheses}

The results for the chi-square $\left(\chi^{2}\right)$, GFI, TLI, CFI and RMSEA showed that the structural model achieved a good level of fit (i.e., $\chi^{2}=336.15, \chi$ ${ }^{2} / \mathrm{df}=2.98, \mathrm{GFI}=0.912, \mathrm{TLI}=0.96, \mathrm{CFI}=0.96$, RMSEA=0.07). In the results, 69 per cent of the variance associated with behavioural intention was accounted for by performance expectancy, perceived desirability, and perceived feasibility, with the individual factors of perceived desirability and perceived feasibility significantly affecting the intention to use IT innovations. Table 2 presents the structural model results.

Table 2: Structural Model Results

\begin{tabular}{|c|l|c|c|c|c|c|}
\hline Hypothesis & & $\boldsymbol{\beta}$ & SE & CR & P-value & \\
\hline H1 & $\begin{array}{l}\text { Performance } \\
\text { Expectancy } \\
\rightarrow \text { Intention }\end{array}$ & 0.053 & 0.081 & 0.948 & 0.343 & No \\
\hline H2 & $\begin{array}{l}\text { Perceived } \\
\text { Desirability } \\
\rightarrow \text { Intention }\end{array}$ & 0.515 & 0.091 & 7.187 & $0.000^{*}$ & Yes \\
\hline H3 & $\begin{array}{l}\text { Perceived Feasibility } \\
\rightarrow \text { Intention }\end{array}$ & 0.326 & 0.062 & 5.735 & $0.000^{*}$ & Yes \\
\hline
\end{tabular}

Note: $\beta$ : Standardized regression weight; SE: Standardized error; CR: Critical ratio; $* \mathrm{p}<0.05$ 


\section{The Effect of Performance Expectancy, Perceived Desirability and Perceived Feasibility}

As shown in Table 2, the effect of performance expectancy on intention to use IT innovation among entrepreneurs was not significant $(\beta=0.05$, $\mathrm{p}=0.34)$. However, on examining the impact of age and gender, the results showed that the young entrepreneurs $(\beta=0.31, p=0.00)$ and male entrepreneurs $(\beta=0.18, p=0.00)$ were more likely to use IT innovation in their work when they expected high performance from using the IT innovation. Therefore, H1 was supported.

The effect of perceived desirability on behaviour intention was significant $(\beta=0.52, p=0.00)$. This showed that the entrepreneurs with higher perceived desirability were more likely to use the IT innovation in their business activities. The chi-square results demonstrated that the two models for male entrepreneurs and female entrepreneurs were different in terms of the association between perceived desirability and intention to use IT innovation. Although perceived desirability was an important determinant towards intention to use IT innovation for both the male and female entrepreneurs, the impact was stronger for the female entrepreneurs $(\beta=0.588, p=0.01)$ than for the male entrepreneurs $(\beta=0.48, p=0.08)$. In terms of age, the association between perceived desirability and intention to use IT innovation was stronger for the younger entrepreneurs $(\beta=0.58, p=0.08)$ than the older entrepreneurs $(\beta=0.47, \mathrm{p}=0.00)$. Therefore, $\mathrm{H} 2$ was supported.

The effect of perceived feasibility on intention to use IT innovation was also significant $(\beta=0.33, p=0.00)$. It can be assumed that intention to use IT innovation would increase as an entrepreneur's ability to adopt and work with IT innovation increased. Both male and female entrepreneurs were significantly affected by the association between perceived feasibility and intention to use IT innovation, with a stronger effect for the female entrepreneurs $(\beta=0.41, p=0.00)$ than for the male entrepreneurs $(\beta=0.26$, $\mathrm{p}=0.00$ ). It appeared that having the appropriate skill and ability to use IT innovation was of more concern to the female entrepreneurs (see Table 3). Age tended to moderate the association between perceived feasibility and intention to use IT innovation. It appeared that skill and capability were not the determining factors toward intention to use IT innovation among the younger entrepreneurs $(\beta=0.06, p=0.60)$ as they may have the necessary 
prior skill and ability to use IT innovation as compared to older entrepreneurs $(\beta=0.39, \mathrm{p}=0.00)$. Therefore, $\mathrm{H} 3$ was supported.

Table 3: Hypotheses Testing on Moderating Effects of Gender and Age

\begin{tabular}{|c|l|c|c|c|}
\hline Hypothesis & & $\boldsymbol{\beta}$ & CR & P \\
\hline \multirow{5}{*}{ H1a } & Performance expectancy $\rightarrow$ Intention & & & \\
\cline { 2 - 5 } & Male (n=306) & 0.179 & 2.666 & $0.008^{*}$ \\
\cline { 2 - 5 } & Female (n=106) & -0.157 & 1.415 & 0.157 \\
\cline { 2 - 5 } & Younger (n=127) & 0.305 & 2.744 & $0.006^{*}$ \\
\cline { 2 - 5 } & Older (n=285) & 0.000 & 0.006 & 0.995 \\
\hline \multirow{5}{*}{ H2a } & Perceived desirability $\rightarrow$ Intention & & & \\
\cline { 2 - 5 } & Male (n=306) & 0.479 & 5.703 & $0.000^{*}$ \\
\cline { 2 - 5 } & Female (n=106) & 0.582 & 4.225 & $0.000^{*}$ \\
\cline { 2 - 5 } & Younger (n=127) & 0.557 & 4.168 & $0.000^{*}$ \\
\cline { 2 - 5 } & Older (n=285) & 0.467 & 5.534 & $0.000^{*}$ \\
\hline \multirow{5}{*}{ H3a } & Perceived feasibility $\rightarrow$ Intention & & & \\
\cline { 2 - 5 } & Male (n=306) & 0.257 & 3.896 & $0.000^{*}$ \\
\cline { 2 - 5 } & Female (n=106) & 0.410 & 3.742 & $0.000^{*}$ \\
\cline { 2 - 5 } & Younger (n=127) & 0.060 & 0.482 & 0.630 \\
\cline { 2 - 5 } & Older (n=285) & 0.394 & 5.977 & $0.000^{*}$ \\
\hline
\end{tabular}

Note: $\beta$ : Standardized regression weights; CR: Critical ratio; ${ }^{*} \mathrm{p} \leq 0.05$

\section{The Moderating Effect of Precipitating Events and Propensity to Act}

To test the moderating variables of precipitating events and propensity, this study split the sample into two groups based on their mean score (i.e., high and low groups) (Hair et al., 2006). As shown in Table 4, the impact of performance expectancy on intention to use IT innovation was higher for the group of entrepreneurs who had experienced high levels of precipitating events $(\beta=0.30, p=0.00)$ than those who had experienced a low level of precipitating events $(\beta=-012, p=0.10)$. Therefore, $\mathrm{H} 4 \mathrm{a}$ was supported.

The group of entrepreneurs who had experienced a low level of precipitating events tended to have a higher level of desirability $(\beta=0.60$, $\mathrm{p}=0.00$ ) than the group who had experienced a high level of precipitating events $(\beta=0.32, \mathrm{p}=0.00)$. Therefore, $\mathrm{H} 4 \mathrm{~b}$ was supported (see Table 4). Regarding the impact of perceived feasibility on intention to use IT innovation, perceived feasibility tended to have a greater impact on higher intention for the group of entrepreneurs with a low level of precipitating events $(\beta=0.26, p=0.00)$ than for the group with a high level of precipitating 
events $(\beta=0.32, p=0.01)$. These results suggested that where the changes in work conditions, work environments and technology are very high, entrepreneurs are not willing to invest in IT innovation. Therefore, $\mathrm{H} 4 \mathrm{c}$ was supported.

Table 4:Hypotheses Testing on Moderating Effects of Precipitating Events

\begin{tabular}{|c|l|c|c|c|}
\hline Hypothesis & & $\boldsymbol{\beta}$ & CR & P \\
\hline \multirow{5}{*}{ H4a } & Performance expectancy $\rightarrow$ Intention & & & \\
\cline { 2 - 5 } & Low (n=172) & -0.121 & 1.663 & 0.096 \\
\cline { 2 - 5 } & High (n=240) & 0.302 & 3.433 & $0.000^{*}$ \\
\hline \multirow{3}{*}{ H4b } & Perceived desirability $\rightarrow$ Intention & & & \\
\cline { 2 - 5 } & Low (n=172) & 0.604 & 6.237 & $0.000^{*}$ \\
\cline { 2 - 5 } & High (n=240) & 0.318 & 3.186 & $0.001^{*}$ \\
\hline \multirow{3}{*}{ H4c } & Perceived feasibility $\rightarrow$ Intention & & & \\
\cline { 2 - 5 } & Low $(\mathrm{n}=172)$ & 0.426 & 5.472 & $0.000^{*}$ \\
\cline { 2 - 5 } & High (n=240) & 0.218 & 2.729 & $0.006^{*}$ \\
\hline
\end{tabular}

Note: $\beta$ : Standardized regression weights; CR: Critical ratio; * $\mathrm{p} \leq 0.05$

As shown in Table 5, the propensity to act did not moderate the relationship between performance expectancy and intention to use IT innovation $(\beta=-0.12, p=0.10)$. Therefore, H5a was not supported. When examining the relationship between perceived desirability and entrepreneurs' intention to use IT innovation, the impact was greater for the group of entrepreneurs with high propensity to act $(\beta=0.55, \mathrm{p}=0.00)$ than for the group of entrepreneurs with low propensity to act $(\beta=0.27, p=0.01)$. Therefore, H5b was supported. Exploring the effect of perceived feasibility on intention to use IT innovation, the impact was greater for the group of entrepreneurs with high propensity to act $(\beta=0.63, \mathrm{p}=0.00)$ than for those with low propensity to act $(\beta=0.16, p=0.04)$. Therefore, $\mathrm{H} 5 \mathrm{c}$ was supported.

Table 5: Hypotheses Testing on Moderating Effects of Propensity to Act

\begin{tabular}{|c|l|c|c|c|}
\hline Hypothesis & & $\boldsymbol{\beta}$ & $\mathbf{C R}$ & $\mathbf{P}$ \\
\hline \multirow{3}{*}{ H5a } & Performance expectancy $\rightarrow$ Intention & H5a & & \\
\cline { 2 - 5 } & Low group $(\mathrm{n}=158)$ & & -0.053 & 0.610 \\
\cline { 2 - 5 } & High group (n=254) & & 0.060 & 0.755 \\
\hline \multirow{3}{*}{ H5b } & Perceived desirability $\rightarrow$ Intention & H5b & & \\
\cline { 2 - 5 } & Low group ( $=158)$ & & 0.272 & 2.677 \\
\cline { 2 - 5 } & High group (n=254) & & 0.553 & 5.392 \\
\hline
\end{tabular}


Table 5:Hypotheses Testing on Moderating Effects of Propensity to Act (Contd.)

\begin{tabular}{|c|l|c|c|c|}
\hline Hypothesis & & 及 & CR & P \\
\hline \multirow{3}{*}{ H5c } & Perceived feasibility $\rightarrow$ Intention & H5c & & \\
\cline { 2 - 5 } & Low group $(\mathrm{n}=158)$ & & 0.160 & 2.049 \\
\cline { 2 - 5 } & High group (n=254) & & 0.628 & 6.333 \\
\hline
\end{tabular}

Note: $\beta$ : Standardized regression weights; CR: Critical ratio; ${ }^{*} \mathrm{p} \leq 0.05$

\section{Discussion}

This study aimed to measure individuals' perceptions towards technology adoption, particularly, the perceptions of entrepreneurs. The findings indicated that the salient factors in determining the intention to use IT innovation among entrepreneurs are the perceived desirability toward the IT innovation and the high perception of the entrepreneur's own capability to use it, that is, the entrepreneurs' perceived feasibility.

These results suggested that at the beginning, an individual will consider the attractiveness of the technology and the desirability to use the IT innovation. If the IT innovation is not attractive to the entrepreneurs, they have no desire to use it, so they will ignore the innovation. In other words, entrepreneurs will consider adopting IT innovation if the new technology attracts their attention. Many useful technologies introduced to the market have failed due to the fact that they could not command the attention of the target audiences. Linan and Santos (2007) and Shook and Bratianu (2008) emphasized the importance of perceived desirability for entrepreneurs to form an intention and to take action. On that note, the effect of perceived desirability on intention to use IT innovation is stronger for female and younger entrepreneurs. Female entrepreneurs seem to perceive that using IT innovation would make their business more fashionable and attractive. The younger entrepreneurs seem to be more technology-oriented and keep themselves updated on the latest trends in IT advancement; thus, they perceive IT innovations to be fashionable and attractive. To male and older entrepreneurs, this determinant is not their main priority, even though they do consider the attractiveness in making their adoption decision. The male and younger entrepreneurs focus more on the profit and gain that can be realized from the use of the innovation; thus, they place priority on the extrinsic rewards of using IT innovation. Venkatesh and Zhang (2010) state the male and younger age group normally have stronger desire to be 
successful and are more interested in job performance accomplishment as they are ambitious and achievement-oriented.

The first factor which affected entrepreneurs' intention to adopt IT innovation is the attractiveness of the technology. When they find the new technology attractive and interesting to use they will evaluate their capability and the feasibility of using the technology. If entrepreneurs perceive they have the skill and ability, they are more interested in using IT innovation, regardless of whether or not the IT innovation is useful and/or user-friendly. The effect of perceived feasibility on intention to use IT innovation seems to be stronger for female and older entrepreneurs. It seems that female and older entrepreneurs will not use IT innovation if they do not have the skill and ability to use it. According to Murphy et al. (1989), female and male entrepreneurs are different in their use of computers for professional work, with male entrepreneurs highest in the order of using IT, especially at the advanced state. Therefore, the skill or ability to use IT innovation is not the salient factor for them. Younger entrepreneurs have grown up with the IT advances and IT has always been part of their lives. As such, they could not easily imagine a world without IT, especially the Internet or cell phone, and they prefer to communicate using email and text messaging rather than face-to-face. Thus, they may perceive that they can manage using the technology. They have the capability to use IT innovation through life experience, and are more confident with IT, so they are able to learn on their own. Surprisingly, the effect of performance expectancy was not strong compared to the perceived desirability and perceived feasibility. The results confirm our arguments that there are other factors which will affect individual intention to adopt and use new technology. Individuals will adopt and use new technology if the new technology can attract their attention and they think that using this technology is feasible for them regardless of how useful a technology might be. Therefore, using the new technology not only depends on the usefulness of the technology. These finding create useful knowledge for industry players and designers when designing or marketing new technology.

These findings reveal that the impacts of perceived desirability and perceived feasibility on the intention to use are greater when entrepreneurs have a strong tendency to act upon the action that they have decided to 
make. In other words, the high propensity to use increases the level of perceived desirability and perceived feasibility of entrepreneurs' intentions to use IT innovation. These findings confirm the arguments made by Krueger and Brazeal (1994) and Bagozzi and Yi (1989) that it is difficult to envision well-formed intentions among entrepreneurs without some propensity to use. As for precipitating events, entrepreneurs' experiences (such as changes in the work environment, work situation or technical conditions) do have an impact on the association between perceived desirability and perceived feasibility and intention to use IT innovation. The precipitating events can be positive (e.g., new contract, new customer, market change, international opportunity) or negative (e.g., declining profit, government policy, financial crisis, rising cost). Entrepreneurs will consider using IT innovation if the IT innovation makes tremendous change in their business and creates new opportunities for them. If the environment and technical changes challenge their survival and affect other situations during negative conditions, the entrepreneurs may not be interested in using IT innovation. On the other hand, if the change is to a better condition, then the impact of these precipitating events is greater on the association between perceived feasibility and the intention to use IT innovation. Thus, the levels of these precipitating events encourage entrepreneurs to consider the available alternatives regarding the best way to use IT innovation.

\section{Conclusion}

Overall, the results of this study significantly enhanced the understanding of the entrepreneur's technology adoption and use behaviour. Thus, several theoretical implications were derived from this study. One of the theoretical implications is the validation of the EPM in the IT innovation adoption context. The technology adoption decision model places greater emphasis on examining the key factors of individual technology adoption and intention to use. This model is able to measure the individual internal desirability and capability of using new technology. It showed that individual intention to start using new technology initially will be affected by internal factors such as individual perceived desirability and perceived feasibility to adopt new technology rather than by the characteristics of the new technology such as ease of use and performance expectancy. However, the effect is different among entrepreneurs of different age and gender. Therefore, future research should consider the desirability and feasibility of 
using new technology when measuring the rate of adoption and use of the new technology. Incorporating perceived desirability and perceived feasibility as determinants in the technology adoption decision model will contribute to a more systematic framework that is unique to technology acceptance. The technology adoption decision model extended the understanding of IT innovation adoption behaviour. Moreover, the inclusion of the two elements of perceived desirability and perceived feasibility is expected to extend further knowledge in IT adoption behaviour research.

Moreover, this study focuses on the displacement events (precipitating factors) that impact the perceptions of entrepreneurs towards the intention to use IT innovation. This finding emphasized the effect of external factors which prevent or facilitate the adoption and use of technology. This study provided evidence concerning the role of precipitating events (external factors) which encourage or inhibit entrepreneurs' to use IT innovation. In addition, the effect of government policy, environmental factors and the work situation on entrepreneurs' intentions to use IT innovation is relatively important. This study also highlights the importance of volitional aspects of the control that entrepreneurs have on their behaviour. Understanding the effect of the volitional aspect of the individual's behaviour and propensity to act on intention to use IT innovation is another important issue which very few studies have examined in the context of IT adoption.

The findings of this study suggest the necessity to recognize individual desirability and feasibility as valuable enabling factors towards the intention to use IT innovation. This study suggests that the attractiveness and feasibility of using IS play a significant role in facilitating the intention to use among entrepreneurs.

The results provided the evidence that different types of events, such as changes in work situations, changes in work environments, the decision to change career, and changes in technology have different effects on an individual's initial intention to use IT innovation. This study makes clear the effect of government policy, environmental factors and the work situation on entrepreneurs' intentions to use IT innovation. For example, a new rule for using Web2 (Facebook) and import or export IT products will affect the use of these technologies and entrepreneurs' intentions to adopt and use 
them. The results of this study may assist policy-makers and managers who want to increase the use of IT innovation by turning their efforts to other factors such as attractiveness of the technology, perceived feasibility and individual propensity to use new technology. The attractiveness of IT innovation is a factor that IT developers and providers should consider when designing new technology.

This study is an initial test of the technology adoption decision model that should be subjected to further testing and refinement. It was assumed that the scales used (conceptualized) in the model were adequate, but further research should support the strength of these scales. Future research will be necessary to validate the relationships between perceived desirability, perceived feasibility and the intention to use new technology. In particular, more studies are needed to validate the findings of this study, such as by applying the research model in different contexts or cultures. This will provide the opportunity to test the robustness of the model across cultural boundaries.

This study validated the EPM in the context of technology acceptance but did not compare this model with previous models. Future research can use the results of the study and compare the technology adoption decision model with the previous models in technology adoption.

\section{References}

Ajzen, I. (1991). The theory of planned behavior. Organizational Behavior and Human Decision Processes, 50, 179-211.

Ajzen, I. (1988). Attitudes, personality, and behavior. Chicago: Dorsey Press.

Ajzen, I., \& Fishbein, M. (1985). From intention to actions: A theory of planned behaviour. In J. Kuhl \& J. Beckmann (Eds.), Action-control: From cognition to behaviour (11-39). Heidelberg: Springer.

Bandura A. (1995). Self-efficacy in changing societies. Cambridge, (Ed.). England: Cambridge University Press.

Bagozzi, R., \& Yi, Y. (1989).The degree of intention formation as a moderator of the attitude-behaviour relationship. Social Psychology Quarterly, 52, 266-279.

Bandura, A. (1997). Self-efficacy: The exercise of control. New York: Freeman. 
Curral, L., Santos, S.C., \& Caetano, A. (2013). Theoretical foundations on the entrepreneurial potential. Amity Business Journal, 2(1),1-11.

Cheng, Y. (2015). Towards an understanding of the factors affecting $\mathrm{m}$ learning acceptance: Roles of technological characteristics and compatibility, Asia Pacific Management Review, 20, 109-119.

Cheung, G.W., \& Rensvold, R.B. (2002). Evaluating goodness-of-fit indexes for testing measurement invariance. Structural equation modeling. A Multidisciplinary Journal, 9, 233-255.

Coduras, A., Urbano, D., Rojas, A., \& Martinez, S. (2008). The relationship between university supports to entrepreneurship with entrepreneurial activity in Spain: A Gem data based analysis. International Advances in Economic Research, 14, 395-406.

Compeau, D., \& Hinggins, C.A. (1995). Application of social cognitive theory to training for computer skills. Information System Research, 6(2): 118-143.

Damanpour, F., \& Schneider, M. (2006). Phases of the adoption of innovation in organizations: Effects of environment, organization and top managers. British Journal of Management, 17, 215-236.

Davis, F. D. (1989). Perceived usefulness, perceived ease of use, and user acceptance of information technology. MIS Quarterly 13(3), 319-339.

Devonish, D., Alleyne, P., Charles-Soverall, W., Marshall, A.Y., \& Pounder, P. (2010). Explaining entrepreneurial intentions in The Caribbean. International Journal of Entrepreneurial Behavior \& Research, 16, 149-171.

Dissanayake.D. (2014). The impact of perceived desirability and perceived feasibility on entrepreneurial intention among undergraduate students in Sri Lanka: An extended model. Kelaniya Journal of Management, 2 (1), 39-57.

Drnovesk, M., \& Erikson, T. (2005). Competing models of entrepreneurial intentions. Economic and Business Review for Central and SouthEastern, 7, 55-71.

Fitzsimmons, J.R., \& Douglas, E.J. (2011). Interaction between feasibility and desirability in the formation of entrepreneurial intentions. Journal of Business Venturing, 26, 431-440.

Guerrero, M., Rialp, J., \& Urbando, D. (2008). The impact of desirability and feasibility on entrepreneurial intentions: A structural equation model. International Entrepreneurship and Management, 4, 35-50.

Hair, J.F., Black, W.C., Babin, B.J., Anderson, R.E.,\& Tatham, T.L. (2006). Multivariate data analysis. Upper Saddle River, NJ: Prentice Hall.

Igbaria, M., Parasuraman, S., \& Baroudi, J.J. (1996). A motivational model of microcomputer usage. Journal of Management Information System, 13(1), 127-143. 
Katz, J.A. (1992). A psychosocial cognitive model of employment status choice. Entrepreneurship Theory and Practice, 17(1): 29-37.

Kamal, M.M. (2006). IT innovation adoption in the government sector: Identifying the critical success factors. Journal of Enterprise Information Management, 19, 192-222.

Karahanna, E., Straub, D.W., \& Chervany, N.L. (1999). Information technology adoption across time: A cross-sectional comparison of pre-adoption and post-adoption beliefs. MIS Quarterly, 23(2), 183213.

Kimberly, J.R., \& Evanisko, M.J. (1981). Organizational innovation: The influence of individual, organizational, and contextual factors on hospital adoption of technological and administrative innovations. Academy of Management Journal, 24(4), 689-713.

Koivumaki, T., Ristola, A., \& Kesti, M. (2008). The perceptions towards mobile services: An empirical analysis of the role of use facilitators. Pers Ubiquity Computer, 12, 67-75.

Krueger, N., \& Brazeal, D.V. (1994). Entrepreneurial potential and potential entrepreneurs. Entrepreneurship Theory and Practice Journal, 5, 91104.

Krueger, N., Reilly, M.D., \& Carsurud, A.L. (2000). Competing models of entrepreneurial intention. Journal of Business Venturing, 15, 411432.

Krueger, N. (2000). The cognitive infrastructure of opportunity emergence. Entrepreneurship Theory and Practice, 25, 5-23.

Krueger, N. (1993). The Impact of prior entrepreneurial exposure on perceptions of new venture feasibility and desirability. Entrepreneurship \& Regional Development, 5, 315-330.

Krueger, N., \& Schulte, W. (2008). Beyond intent: Antecedents of resilience and precipitating events for social entrepreneurial intention and action. SASBE - Conference Proceedings. 1093.

Krueger, N.J. (1998). Encouraging the identification of environmental opportunities. Organizational Change Management, 11, 174-183.

Krueger, N.J. (2008). Entrepreneurial resilience: Real and perceived barriers to implementing entrepreneurial intentions. TEAMS/Tech Connect. $\mathrm{C} / \mathrm{O}$ Boise State University. Available at: http://ssrn.com/abstract=1155269

Krueger, N., Hansen, D.J., Michl, T., \& Welsh, H.B. (2011). Thinking "sustainability" the role of intentions, cognitions, and emotions in understanding new domains of entrepreneurship - Advance in Entrepreneurship, Firm Emergence and Growth, 13, 275-309. 
Lee, J., \& Runge, J. (2001). Adoption of information technology in small business: Testing drivers of adoption for entrepreneurs. Computer Information Systems, 42, 1-10.

Linan, F., Yi-Wen, C. (2009). Development and cross-cultural application of a specific instrument to measure entrepreneurial intentions. Entrepreneurship Theory and Practice Journal, 5,593-617

Linan, F., \& Santos, J .F. (2007). Does social capital affect entrepreneurial intentions? International Advances in Economic Research, 13, 443453.

Ling, T.C., \& Nasurdin, A.M. (2010) . Human resource management practices and organizational innovation: An empirical study in Malaysia. Applied Business Research, 26 (105). ABI/INFORM Global.

Lyytinen, K., \& Rose, G. M. (2003). The disruptive nature of information technology innovations: The case of internet computing in systems development organizations. MIS Quarterly 27, 557-595.

McDaniel, B.A. (2000). A survey on entrepreneurship and innovation. The Social Science Journal, 37(2), 277-284.

Manh Chu, H., Benzing, C., \& McGee, C. (2007). Ghanian and Kenyan entrepreneurs: A comparative analysis of their motivations, success characteristics and problems. Developmental Entrepreneurship, 12, 295-322.

Meek, M.D. (2004).Antecedents to the entrepreneurial decision: An empirical analysis of three predictive models. Kauffman Dissertation Executive Summary www.kauffman.org/kdfp.

Mhango, M., Marcketti, S., \& Niehm, L. S. (2005). Small retailers' integration of e-commerce technology: Personal and business perspectives of Iowa business owners. Journal of Business and Entrepreneurship, 17, 70-90.

Morris, M.G., \& Venkatesh, V. (2000). Age differences in technology adoption decisions: Implications for a changing workforce. Personnel Psychology, 53, 375-403.

Moghavvemi, S., Salleh, N.A., Zhao, W., \& Mattila, M.M. (2012). The entrepreneur's perception of information technology adoption: An empirical analysis of the role of precipitating events on usage behavior. Innovation: Management, Policy \& Practice.14(2), 231246.

Moghavvemi, S., Salleh, N.A., \& Abessi M. (2013). Determinants of ITrelated innovation acceptance and use behavior: Theoretical integration of unified theory of acceptance and use of technology and entrepreneurial potential model, Journal of Social Technologies 3, 243-260. 
Moghavvemi, S., Salleh, N.A., \& Standing, C. (2016). Entrepreneurs adoption of information system innovation: The impact of individual perception and exogenous factors on entrepreneurs behavior, Internet Research, 26 (5), 1181-1208.

Moore, G.C., \& Benbasat, I. (1991). Development of an instrument to measure the perceptions of adopting an information technology innovation. Information System Research, 2 (3), 192-222.

Murphy, C.A., Coover, D., \&Owen, S.V. (1989). Development and validation of the computer self-efficacy scale. Journal of Educational and Psychological Measurement, 49,893-893.

Nasurdin, A.M., Ahmad, N.H., \& Lin, C.E. (2009). Examining a model of entrepreneurial intention among Malaysians using SEM procedure. European Journal of Scientific Research,33,365-373.

Oruoch, D.M. (2006). Factors that facilitate intention to venture creation among nascent entrepreneurs-Kenyan Case, digitalcase.case.edu:9000/fedora/get/ksl./weaedm161.

Park, J., Yang, S., \& Lehto, X. (2007). Adoption of mobile technologies for Chinese consumer. Journal of Electronic Commerce Research, 8(3), 196-206.

Podsakoff, P.M., MacKenzie, S.B., \& Lee, J.Y. (2003). Common method biases in behavioral research: A critical review of the literature and recommended remedies. Journal of Applied Psychology, 88(5), 879903.

Rogers, E.M. (1995). The diffusion of innovation. $\left(4^{\text {th }}\right.$ ed.). Free Press, New York.

Sam, K.M., \& Chatwin, C. (2015).Online consumer decision-making styles for enhanced understanding of Macau online consumer behavior, Asia Pacific Management Review, 20, 100-107.

Schein, E.H. (1985).Organizational culture and leadership, San Francisco CA, Jossey Bass.

Segal, G., Borgia, B., \& Schoenfeld, J. (2005). The motivation to become an entrepreneur international. Journal of Entrepreneurial Behavior \& Research, 11, 42-57.

Sequeira, J., Mueller, S.L., \& McGee, J.E. (2007). The influence of social ties and self-efficacy in forming entrepreneurial intentions and motivating nascent behavior. Journal of development Entrepreneurship, 12, 275-293.

Schumpeter, J.A. (1936). The theory of economic development: An inquiry into profits, capital credit - Interest and the business cycle. Cambridge: Harvard University Press. 
Simanjuntak,M., Awwaliyah, I., Hayati, H., \& Artanto, R.J. (2016). The entrepreneurial potential among undergraduate students, Jurnal Bisnis dan Manajemen, 17(2), 1-10.

Shapero, A., \& Sokol, L. (1982). The social dimensions of entrepreneurship in encyclopedia of entrepreneurship. New Jersey: Prentice-Hall, Inc.

Shook, C.L.,\& Bratianu, C. (2008). Entrepreneurial intent in a transitional economy: An application of the theory of planned behavior to Romanian students. International Entrepreneurship Management. Springer Science.

Spencer, A.S., Kirchhoff, B.A., \& White, C. (2008). Entrepreneurship, innovation, and wealth distribution: The essence of creative destruction. International Small Business Journal, 26, 9-26.

Straub, E.T. (2009). Understanding technology adoption: Theory and future direction for informal learning. Review of Educational Research, 79, 625-64.

Stopford, J.M., \& Baden-Fuller, C.W.F. (1994). Creating corporate entrepreneurship. Strategic Management Journal 15(7), 521-536.

Taylor, S., \& Todd, P.A. (1995). Understanding information technology usage: A test of competing models. Information system Research 6(2): 144-177.

Thompson, R.L., Higgins C.A., \& Howell, J.M. (1991). Personal computing: Towards a conceptual model of utilization. MIS Quarterly 15(1), 125-143.

Tornatzky, L.G., \&Fleischer, M. (1990). The processes of technological innovation. Lexington Books, Lexington, MA.

Triandis, H.C. (1977). Interpersonal behaviour. Brooks/Cole Publishers, Monterey, CA.

Tsai, C.M. (2009). The knowledge diffusion model associated with innovative knowledge. Expert Systems with Applications, 36, 1132311331.

Veciana, J.M., Aponte, M., \& Urbano, D. (2005). University students' attitudes towards entrepreneurship: A two countries comparison. International Entrepreneurship and Management, 1,165-182.

Venkatesh, V., Morris, M.G, Davis, G.B., \& Davis, F.D.(2003). User acceptance of information technology: Toward a unified view. MIS Quarterly, 27, 425-478.

Venkatesh, V., \& Davis, F.D. (2000). A theoretical extension of the technology acceptance model: Four longitudinal field studies. Management Science, 45,186-204.

Venkatesh, V., Davis, F.D., \& Morris, M. (2007). Dead or alive? The development, trajectory and future of technology adoption research. Association for Information Systems, 8, 267-286. 
Venkatesh, V., \& Zhang, X. (2010). Unified theory of acceptance and use of technology: U.S. Vs. China. Journal of Global Information Technology Management 13(1),5-27, ABC/ INFORM Global.

Venkatesh, V., Thong, J.Y.L., \& Xu, X. (2012). Consumer acceptance and use of information technology: Extending the unified theory of acceptance and use of technology. MIS Quarterly, 36(1), 157-178.

Wang, C., Liu, W., Tseng, M., \& Tsai, H. (2010). A study of Taiwanese college teachers' acceptance of distance learning. International Journal of Organizational Innovation, 3(2), 243-260.

Zampetakis, L.A. (2008). The role of creativity and proactively on perceived entrepreneurial desirability. Thinking Skills and Creativity, 154-162.

Zhao, Y., \& Cavusgil, S.T. (2006). The effect of supplier's market orientation on manufacture's trust. Industrial Marketing Management 35, 405-414. 
Appendix 1: Factor Loading and Cronbach's Alpha Value for Each Construct

\begin{tabular}{|c|c|c|c|}
\hline Variables & Sources & $\begin{array}{c}\text { Factor } \\
\text { loading }\end{array}$ & $\begin{array}{c}\text { Cronbach } \\
\text { Alpha } \alpha\end{array}$ \\
\hline $\begin{array}{l}\text { Performance Expectancy } \\
\text { I find the IS innovation to be useful in my } \\
\text { business. } \\
\text { Using the IS innovations enable me to accomplish } \\
\text { tasks more quickly. } \\
\text { Using IS innovation increase my productivity. } \\
\text { Using IS innovation, increase my chances of } \\
\text { getting more benefit in my business. } \\
\text { Using IS innovation gives me competitiveness } \\
\text { power in my business. }\end{array}$ & $\begin{array}{c}\text { Venkates, } \\
\text { et al. } \\
(2003)\end{array}$ & $\begin{array}{l}.813 \\
.872 \\
.890 \\
.892 \\
.838\end{array}$ & .916 \\
\hline $\begin{array}{l}\text { Perceived Desirability } \\
\text { Using IS innovation in my business is much more } \\
\text { desirable for me. } \\
\text { I would enjoy the personal satisfaction of using IS } \\
\text { innovation in my business. } \\
\text { Using IS innovation would increase quality of } \\
\text { work in my business. } \\
\text { Using IS innovation in my business is an attractive } \\
\text { idea. } \\
\text { I am very enthusiastic to use IS innovation in my } \\
\text { business. } \\
\text { The success of my business lies in the use of IS } \\
\text { innovation. } \\
\text { Using IS innovation would result in a more relax } \\
\text { working environment in my business. }\end{array}$ & $\begin{array}{c}\text { Krueger } \\
\text { (1993) }\end{array}$ & $\begin{array}{l}.797 \\
.844 \\
.836 \\
.863 \\
.843 \\
.758 \\
.756\end{array}$ & .929 \\
\hline $\begin{array}{l}\text { Perceived Feasibility } \\
\text { I am able to use the IS innovation even if there is } \\
\text { no one around to show me how to use it. } \\
\text { I would feel comfortable using IS innovation in } \\
\text { my business. } \\
\text { I have the skills and capabilities required to use IS } \\
\text { innovation. } \\
\text { I am confident I can put in the effort needed to use } \\
\text { new IS innovation in my business. } \\
\text { It would be very practical for me to use new IS } \\
\text { innovation in my business. } \\
\text { It would be very feasible for me to use IS } \\
\text { innovation in my business. }\end{array}$ & $\begin{array}{c}\text { Krueger } \\
\text { (1993) }\end{array}$ & $\begin{array}{l}.677 \\
.836 \\
.820 \\
.876 \\
.905 \\
.882\end{array}$ & .929 \\
\hline $\begin{array}{l}\text { Propensity to Act } \\
\text { I will learn to operate IS innovation in my } \\
\text { business. } \\
\text { I will use IS innovation to achieve more } \\
\text { opportunity in my business. }\end{array}$ & & & \\
\hline
\end{tabular}




\begin{tabular}{|c|c|c|c|}
\hline $\begin{array}{l}\text { I will use IS innovation because I cherish the } \\
\text { feeling of a useful service. } \\
\text { I will use IS innovations that enable me to run my } \\
\text { business successfully. }\end{array}$ & $\begin{array}{c}\text { Krueger } \\
(1993)\end{array}$ & $\begin{array}{l}.718 \\
.812 \\
.880 \\
.722\end{array}$ & .934 \\
\hline $\begin{array}{l}\text { Intention to Use } \\
\text { I predict I would use IS innovation, if it is } \\
\text { available in the future. } \\
\text { My personal philosophy is to do whatever it takes } \\
\text { using IS innovation in the future. } \\
\text { I have very seriously thought of using IS } \\
\text { innovation in my business if it available, in next } 2 \\
\text { months. } \\
\text { I plan to use current IS innovation in my work in } \\
\text { the next year. } \\
\text { I intent to use similar IS innovation technology in } \\
\text { the future. }\end{array}$ & $\begin{array}{l}\text { Venkates, } \\
\text { et al. } \\
(2003)\end{array}$ & $\begin{array}{l}.773 \\
.848 \\
.881 \\
.876 \\
.846\end{array}$ & 0.924 \\
\hline $\begin{array}{l}\text { Precipitating Events } \\
\text { If you experience any changes in your work } \\
\text { situation (For example; being offered a big } \\
\text { contract, declining profit, availability of financial } \\
\text { resource, new investment, rising cost, new } \\
\text { product), how much have these changes influenced } \\
\text { your decision in using IS innovation? } \\
\text {-If you experience any change in your work } \\
\text { environment (for example, government policy, } \\
\text { financial crisis, customer or new market, supplier } \\
\text { request, industry or market change, declining } \\
\text { market share), how much have these changes } \\
\text { influenced your decision in using IS innovation? } \\
\text {-If you decided to change your work situation, due } \\
\text { to recent opportunity or lack of opportunity(for } \\
\text { example; competitive nature of environment, } \\
\text { competitor threat or action, strategic growth target, } \\
\text { perception of increasing risk, attract new customer, } \\
\text { international opportunities), how much have these } \\
\text { assessments influenced your decision in using IS } \\
\text { innovation? } \\
\text {-If you experience any technical change in your } \\
\text { work environment (for example, availability of IT } \\
\text { innovation, technological change, new technology } \\
\text { in accounting practice, availability of on line } \\
\text { system), how much have these changes influenced } \\
\text { your decision in using IS innovation? }\end{array}$ & $\begin{array}{c}\text { Kruger\& } \\
\text { Brazeal } \\
(1994) \\
\text { Schindehutt, } \\
\text { et al. } \\
\text { (2000) }\end{array}$ & $\begin{array}{l}.785 \\
.875 \\
.844 \\
.744\end{array}$ & .861 \\
\hline
\end{tabular}

Source: Survey Data 
Appendix 2: Summary of the Benchmark for Model Fit indices

\begin{tabular}{|l|c|c|}
\hline Name of Model Fit Index & Abbreviate & Cutoff Value \\
\hline Normal Chi-Square $\left(\chi^{2} / \mathrm{df}\right)$ & CMIN/DF & $1<\chi^{2} / \mathrm{df}<3$ \\
\hline Goodness-of-fit Index & GFI & GFI $>0.90$ \\
\hline $\begin{array}{l}\text { Adjusted Goodness-of-fit Index } \\
\text { Root Mean Square Error of } \\
\text { Approximation }\end{array}$ & AGFI & $\begin{array}{c}\text { AGFI }>0.90 \\
/ 0.80\end{array}$ \\
\hline $\begin{array}{l}\text { Tucker-Lewis Index } \\
\text { Comparative Fit Index }\end{array}$ & TLI & RMSEA $<0.08$ \\
\hline
\end{tabular}

Source: Survey Data 